\title{
Keefektifan Pembelajaran Pendidikan Islam Secara Daring Di Tengah Situasi Social Distancing Akibat Penyebaran Covid-19 "Di Madrasah Aliyah Negeri 2 Bantul"
}

\author{
Aretsa Zana Ayunda
}

Universitas Ahmad Dahlan

\begin{tabular}{l}
\hline Info Artikel : \\
\hline Diterima 12 Mei 2020 \\
Direvisi 13 Agustus \\
2020 \\
Dipublikasikan 26 \\
Oktober 2020 \\
\end{tabular}

\section{Kata Kunci:}

Pendidikan islam

Pembelajaran daring

Covid-19

Social distancing

Keywords:

Islamic education

Online learning

Covid-19

Social distancing

\begin{abstract}
ABSTRAK Abstract
Pendidikan merupakan hal yang sangat Education is very important in today's penting di kalangan masyarakat saat ini, society, especially Islamic education. To terutama pendidikan islam. Untuk obtain education, an institution is needed. memperoleh pendidikan, dibutuhkan suatu One of Islamic education institutions is lembaga. Salah satu lembaga pendidikan islam madrasa. In addition to the important role
\end{abstract}

yaitu madrasah. Selain peran penting suatu lembaga dalam memperoleh pendidikan, keefektifan dalam pembelajaran juga diutamakan. Akan tetapi saat ini kita tengah berada dalam situasi social distancing akibat penyebaran Covid-19 yang membuat pembelajaran tidak bisa dilakukan secara g. Sehingga sistem pembelajaran saat is replaced using an online learning ini diganti menggunakan sistem pembelajaran system. This study aims to determine the secara daring. Penelitian ini bertujuan untuk effectiveness of online learning from mengetahui keefektifan pembelajaran secara students of Madrasah Aliyah Negeri 2 daring dari peserta didik Madrasah Aliyah Bantul in social distancing situations due Negeri 2 Bantul dalam situasi social distancing to the spread of Covid-19. This research is akibat penyebaran Covid-19. Penelitian ini a class action research with research merupakan penelitian tindakan kelas dengan subjects are students of Madrasah Aliyah subjek penelitian adalah peserta didik Negeri 2 Bantul class X, XI, XII both men Madrasah Aliyah Negeri 2 Bantul kelas X, XI, and women. The technique of data XII baik laki-laki maupun perempuan. Teknik acquisition is observation through google perolehan data adalah observasi melalui media acquisition is obserwation through google google form atau google formulir. Untuk media forms or google forms. To suppon dilakukan secara daring, pendidik educators use several social media. From menggunakan beberapa media sosial. Dari the results of the study, although it has hasil penelitian, meski sudah didukung dengan been supported by social media, students media sosial, peserta didik berpendapat bahwa argue that learning does not work pembelajaran tidak berjalan efektif. Ada effectively. There are several advantages beberapa kelebihan dan kekurangan dalam and disadvantages to online learning. Even pembelajaran secara daring. Meski begitu, so, students still have to do online learning peserta didik tetap harus melakukan to reduce the spread of Covid-19. pembelajaran secara daring untuk mengurangi penyebaran Covid-19.

\section{Koresponden:}

Aretsa Zana Ayunda,

Email: aretsa1900031038@webmail.uad.ac.id 


\section{Pendahuluan}

Pada saat ini, pendidikan merupakan hal yang dianggap penting oleh berbagai kalangan. Karena pendidikan mempunyai kaitan yang kuat terhadap pengetahuan. Suatu pengetahuan menjadi motivasi bagi seseorang untuk menjalani suatu proses pendidikan. Dalam suatu kehidupan pendidikan mempunyai peranan yang cukup penting, untuk membentuk suatu kepribadian, mengembangkan seluruh potensi, serta menggali bakat bisa didapatkan melalui pendidikan oleh peserta didik. Mengembangkan dan membentuk kepribadian peserta didik tidak hanya melalui pendidikan umum, pendidikan islam juga dibutuhkan untuk membentuk kepribadian seorang peserta didik. Karena pendidikan islam merupakan suatu pondasi yang harus dibangun sejak dini agar nantinya kepribadian peserta didik terbentuk dengan baik sesuai dengan ajaran agama islam. Melalui pendidikan islam, seorang peserta didik akan diajarkan bagaimana berperilaku yang sesuai dengan ajaran islam. Sasaran yang hendak dicapai ialah terbentuknya akhlak yang mulia, serta mempunyai ilmu yang tinggi dan taat beribadah. (Mappasiara, 2018) Pendidikan juga tidak jauh dari neurosains. Neurosains merupakan suatu sistem pendidikan yang baru, di dalam neurosains akan didapatkan suatu pengetahuan tentang sistim kerja syaraf. Sistim kerja syaraf itu sendiri berperan untuk menerima, mengolah, dan menyampaikan rangsangan dari seluruh organ tubuh. Tetapi pada era ini, jarang pendidik yang memperhatikan permasalahan mengenai sistem kerja syaraf, padahal pengabaian terhadap sistem kerja syaraf dapat menyebabkan suasana pembelajaran menjadi mati. Sehingga menimbulkan suasana pembelajaran yang cenderung membosankan. Seperti yang diketahui dalam suatu dunia pendidikan, suatu proses pembelajaran dan kebijaksanaan pembelajaran bersumber dari peserta didik itu sendiri. Dunia pendidikan yang sudah mengenal dan menyentuh ilmu neurosains dalam suatu implementasi pembelajaran pastinya sudah mengalami banyak sekali perubahan. Karena sebagai pendidik, dituntut untuk mengubah pembelajaran yang cenderung menggunakan pembelajaran model lama digantikan kepada manageman pendidik yang kreatif dengan metode neurosains. Neurosains dapat membuat hubungan diantara proses kognitif yang terdapat di dalam otak dengan tingkah laku yang akan dihasilkan. (Hengki, 2018) Jika ditelusuri secara historis, neurosains mempunyai akar sejarah keilmuan yang cukup panjang, terlebih lagi dalam tradisi pemikiran Islam. Pesatnya perkembangan neurosains dapat dilacak jejaknya dalam khazanah pemikiran Islam, baik klasik maupun modern. Jejak tersebut setidaknya dapat ditemukan dalam kajian filsafat Islam, tasawuf dan ushul figh. (Suryono, 2014) Dalam memperoleh pendidikan, baik pendidikan umum, pendidikan islam, maupun yang ada kaitannya dengan neurosains tentunya membutuhkan suatu lembaga pendidikan. Salah satu lembaga pendidikan islam yang ada di Indonesia adalah madrasah.

Seperti yang diketahui, madrasah merupakan salah satu lembaga pendidikan islam di Indonesia. Keberadaan madrasah cukup penting dalam menciptakan suatu penerus bangsa yang berwawasan keislaman. Dari sekian banyak kelebihan yang dimiliki madrasah, salah satunya adalah adanya integrasi ilmu umum dan ilmu agama. Madrasah juga berperan sangat penting dalam menciptakan generasi penerus bangsa yang paham akan ajaran islam. Namun demikian, dalam pelaksanaannya pendidikan di madrasah seringkali masih dipandang sebelah mata. Madrasah dianggap sebagai pendidikan kelas dua setelah pendidikan formal yang diselenggarakan kemendikbud. (Alawiyah, 2014) Banyak masyarakat yang menganggap bahwa pendidikan di madrasah dinilai kurang berkualitas. Bahkan tidak sedikit yang menjadikan madrasah sebagai pilihan kedua atau bahkan pilihan terakhir dalam pendidikan. Tidak sedikit pula yang menganggap bahwa lulusan madrasah tidak sama dengan lulusan dari pendidikan formal. Padahal, saat ini madrasah sudah mulai berkembang. Kualitas pendidikannya pun sudah hampir sama dengan kualitas pendidikan formal. Apalagi di era yang krisis moral yang terjadi saat ini, pendidikan di madrasah dirasa sangat perlu untuk memperbaiki kepribadian dan moral seorang peserta didik. Di madrasah juga peserta didik akan dididik cara bertingkah laku yang sesuai dengan ajaran agama islam. Karena itu madrasah mempunyai peran yang cukup penting dalam pendidikan nasional untuk membangun generasi bangsa yang berakhlak mulia. Selain peran penting suatu lembaga untuk pendidikan bagi peserta didik, keefektifan pembelajaran juga diperlukan dalam proses pendidikan. Keefektifan akan didapatkan setelah dilaksanakannya proses pembelajaran, jika dalam proses pembelajaran berlangsung 
efektif, maka pembelajaran yang didapat akan bermanfaat dalam kehidupan, terutama kehidupan seharihari. Keefektifan dalam pembelajaran, biasanya didapat dari metode atau cara-cara yang diberikan oleh pendidik untuk menyampaikan pengetahuannya kepada peserta didik. Suatu pembelajaran bisa dikatakan efektif apabila telah mencapai tingkat keberhasilan dalam pencapaian tujuan pembelajaran. (Cruz, 2013) Ada banyak faktor yang mempengaruhi pencapaian tujuan pembelajaran. Salah satu faktor terbesar yang cukup penting adalah pendidik itu sendiri. Seorang pendidik harus paham materi dan metode apa yang akan disampaikan kepada peserta didik sehingga pembelajaran bisa berlangsung efektfif. Pada hakikatnya, keefektifan pembelajaran mempunyai keterkaitan dengan interaksi atau hubungan antara pendidik dan peserta didik. Suatu pembelajaran akan berjalan dengan baik dan efektif apabila proses interaksi antara pendidik dan peserta didik di dalam kelas berjalan dengan baik. Sebaliknya, apabila proses interaksi antara pendidik dan peserta didik tidak terjalin dengan baik, maka proses pembelajaran tidak berjalan efektif. Proses interaksi antara pendidik dan peserta didik biasanya di lakukan di dalam kelas saat di madrasah. Akan tetapi akibat adanya penyebaran covid-19 yang tengah terjadi saat ini, tidak memungkinkan untuk pendidik dan peserta didik melakukan interaksi pembelajaran secara langsung di dalam kelas.

Covid-19 merupakan virus RNA strain tunggal positif, berkapsul dan tidak bersegmen. Covid-19 tergolong ordo Nidovirales, keluarga Coronaviridae. Struktur Covid-19 membentuk struktur seperti kubus dengan protein S berlokasi di permukaan virus. Covid-19 bersifat sensitif terhadap panas dan ecara efektif dapat diinaktifkan oleh desinfektan mengandung klorin, pelarut lipid dengan suhu 56 derajat celcius selama 30 menit, eter, alkohol, asam perioksiasetat, detergen non-ionik, formalin, oxidizing agent dan kloroform. Seperti yang kita ketahui, Covid-19 dapat menyebar melalui percikan dari saluran pernafasan seperti batuk atau bersin. Jika dalam situasi seperti ini tetap dilakukan interaksi secara langsung, dikhawatirkan penyebaran Covid-19 semakin cepat. Untuk itu dilakukannya langkah social distancing agar mengurangi penyebaran dari Covid-19. Social distancing adalah langkah-langkah jarak sosial yang diambil untuk membatasi kapan dan di mana orang dapat berkumpul untuk menghentikan atau memperlambat penyebaran penyakit menular. (Health, 2006) Social distancing Jarak sosial dirancang untuk mengurangi interaksi di antara orang-orang dalam komunitas yang lebih luas, di mana individu mungkin berada menular tetapi belum diidentifikasi maka belum diisolasi. (Wilder-Smith \& Freedman, 2020) Dengan berlakunya social distancing saat ini, berdampak juga ke dalam dunia pendidikan, di mana beberapa sekolah umum maupun madrasah tidak bisa melakukan pembelajaran secara langsung. Dalam situasi social distancing lembaga pendidikan salah satunya madrasah, meminta agar peserta didik mengurangi atau menghindari kerumunan banyak orang. Dengan itu, madrasah mengambil langkah belajar dengan pembelajaran secara online, agar peserta didik dapat ikut serta dalam langkah pengurangan penyebaran Covid-19. Seperti yang dilakukan pada salah satu madrasah di Bantul yaitu Madrasah Aliyah Negeri 2 Bantul. Saat ini Madrasah Aliyah 2 Bantul mengambil langkah pembelajaran secara online atau yang sering disebut dengan daring (dalam jaringan). Istilah daring mengacu pada membaca, menulis, dan berkomunikasi menggunakan jaringan komputer. Dalam kata lain, komunikasi daring (dalam jaringan) adalah suatu cara berkomunikasi di mana penyampaian dan penerimaan pesannya dilakukan atau melalui jaringan internet. Di Madrasah Aliyah Negeri 2 Bantul teknologi informasi itu dikembangkan atau diadopsi dan dikemas sesuai dengan prinsip-prinsip teknologi pembelajaran secara online dengan tetap mengutamakan nilai-nilai islam (M. Lubis, 2016) untuk digunakan pembelajaran secara daring di tengah situasi social distancing yang terjadi pada saat ini. 


\section{Metode}

A. Setting Penelitian

1. Obyek dan subjek

a. Subjek penelitian adalah peserta didik Madrasah Aliyah Negeri 2 Bantul sebanyak 65 peseta didik, baik laki-laki maupun perempuan.

b. Objek penelitian adalah keefektifan pembelajaran pendidikan islam secara daring di tengah situasi social distancing akibat penyebaran Covid-19 di Madrasah Aliyah Negeri 2 Bantul.

2. Waktu dan lamanya penelitian

Waktu penelitian dilakukan selama 2 hari melalui google form pada tanggal 02 April 2019 sampai tanggal 04 April 2019

3. Lokasi penelitian

Penelitian tidak dilakukan di lokasi penelitian yaitu Madrasah Aliyah Negeri 2 Bantul, akan tetapi dilakukan secara online melalui media google form. Karena saat ini tengah berada dalam situasi social distancing akibat penyebaran Covid-19.

B. Rencana Tindakan

1. Perencanaan

Peneliti membuat beberapa susunan pertanyaan di google form mengenai tanggapan dari peserta didik adanya social distancing yang tengah terjadi saat ini. Pertanyaan tersebut antara lain :

a. Nama

b. Kelas

c. Bagaimana pendapat anda tentang dampak dari situasi social distancing akibat penyebaran covid-19 terhadap pembelajaran saat ini?

d. Di tengah situasi social distancing ini pembelajaran dilakukan secara online. Aplikasi apa saja yang digunakan oleh guru untuk mendukung pembelajaran agar tetap berjalan efektif?

e. Dengan menggunakan aplikasi tersebut, apakah pembelajaran tetap berlangsung efektif?

f. Jika iya, berikan alasannya!

g. Jika tidak, berikan alasannya!

h. Apa pendapat anda tentang kelebihan pembelajaran secara online?

i. Apa pendapat anda tentang kekurangan pembelajaran secara online?

2. Pelaksanaan tindakan

Setelah melakukan perencaan tindakan, peneliti melakukan pelaksanaan tindakan dengan menyebar link google form kepada peserta didik Madrasah Aliyah 2 Bantul. Peneliti melakukan pengamatan selama 2 hari. Sebanyak 65 peserta didik berpartisipasi untuk mengisi pertanyaan dari peneliti melalui google form. Pengamatan yang dilakukan oleh peneliti meliputi tanggapan dari peserta didik mengenai keefektifan sistem pembelajaran secara daring (dalam jaringan).

3. Pengumpulan data

Peneliti mengecek hasil tanggapan dari perserta didik. Terlihat ada 65 peserta didik yang menanggapi pertanyaan dari peneliti. Peneliti akan membaca hasil dari tanggapan peserta didik untuk kemudian akan di bahas di pembahasan. 


\section{Hasil dan Pembahasan}

Pada umumnya suatu pembelajaran dapat dikatakan efektif apabila seorang pendidik berinteraksi langsung dengan peserta didiknya. Karena proses interaksi antara pendidik dan peserta didik di dalam kelas ketika proses pembelajaran merupakan hubungan timbal balik yang saling mempengaruhi antara keduanya. Hal ini juga ada keterkaitannya dengan fungsi sistim kerja syaraf pusat yang salah satunya adalah menerima atau menangkap suatu rangsangan. Apabila interaksi antara pendidik dan peserta didik dilakukan di dalam kelas, maka akan terjadi hubungan timbal balik yaitu pendidik memberikan suatu pembelajaran kemudian peserta didik menangkap pembelajaran itu. Di dalam kelas suatu interaksi dalam kegiatan pembelajaran bukan hanya penyampaian materi pembelajaran, akan tetapi upaya yang dilakukan oleh pendidik untuk memberikan pembelajaran melalui media atau alat dapat berlangsung dengan baik, sehingga peserta didik dapat memahami dan menerima pembelajaran dengan baik. Namun, karena situasi saat ini yang tidak mendukung dikarenakan tengah berada disituasi social distancing akibat penyebaran Covid19, mengharuskan pendidik dan peserta didik tidak melakukan pembelajaran secara langsung. Walaupun begitu, sistim dan obyek tidak mampu berjalan sempurna tanpa ada subyek. Subyek di sini adalah pendidik yang memahami sistim pembelajaran yang dilakukan. (Wathon, 2016) Dikarenakan situasi social distancing maka pembelajaran saat ini menggunakan metode pembelajaran secara daring (dalam jaringan). Dengan situasi yang seperti ini, peneliti melakukan penelitian kepada peserta didik Madrasah Aliyah Negeri 2 Bantul, untuk mengetahui keefektifan pembelajaran meski dilakukan secara daring (dalam jaringan) pada situasi social distancing akibat penyebaran Covid-19 yang terjadi saat ini. Untuk mengumpulkan beberapa data yang digunakan untuk penelitian, peneliti menggunakan metode pengumpulan data melalui media google formulir.

Google formulir merupakan suatu media yang dapat digunakan untuk mendapatkan pendapat dari beberapa orang atau mengirim survei yang bisa dibagikan melalui link. Dengan google formulir, pendidik juga dapat memberikan peserta didik suatu kuis dan bisa juga mengumpulkan data atau informasi dengan cara yang mudah dan efisien. Aplikasi ini berbasis web maka setiap orang dapat memberikan tanggapan atau jawaban terhadap kuis ataupun kuisioner secara cepat dimanapun ia berada dengan menggunakan aplikasi internet komputer, laptop, atau smartphone. (Batubara, 2016) Sehingga, hanya dengan menyebarkan link google form, peserta didik atau sasaran yang akan dituju bisa mengisi google form di mana saja dan kapan saja. Mudahnya penggunaan media google form, memunculkan ide bagi peneliti untuk melakukan penelitian dengan cara meminta pendapat kepada peserta didik Madrasah Aliyah Negeri 2 Bantul melalui google form, tanpa harus bertatap muka atau berinteraksi langsung. Penelitian tersebut dilakukan oleh peneliti untuk mengetahui pendapat dari peserta didik mengenai keefektifan pembelajaran yang terjadi saat ini secara daring di tengah situasi social distancing akibat penyebaran Covid-19. Mengetahui keefektifan suatu pembelajaran merupakan hal penting untuk memberikan suatu gambaran kepada pendidik sejauh mana pembelajaran dapat mencapai tujuan. (Cruz, 2013) Untuk itu, pendidik harus mengetahui sejauh mana metode pembelajaran secara daring (dalam jaringan) yang dilakukan saat ini dapat diterima oleh peserta didik dengan baik, dan peserta didik tetap merasakan keefektifan pembelajaran walaupun tidak melalui interaksi secara langsung. Melalui media google form, peneliti mendapatkan jumlah peserta didik yang ikut berpartisipasi untuk memberikan tanggapan mereka tentang keefektifan pembelajaran di tengah situasi social distancing akibat penyebaran Covid-19. 


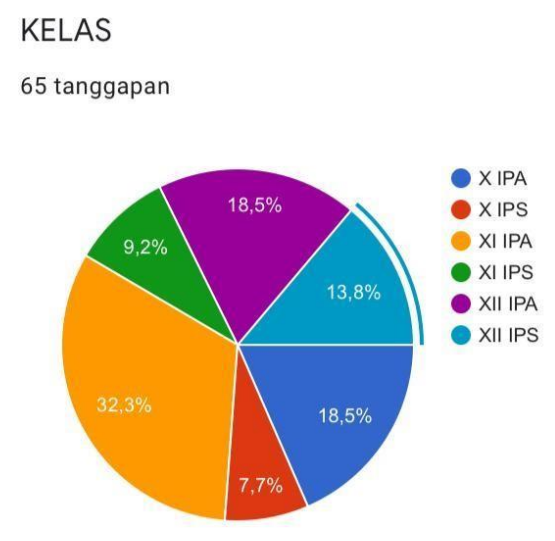

Dari observasi yang dilakukan oleh peneliti, didapat hasil sebanyak 65 peserta didik yang menanggapi pertanyaan dari peneliti melalui media google form. 65 peserta didik tersebut terdiri dari 12 peserta didik kelas X IPA, 5 peserta didik kelas X IPS, 21 peserta didik kelas XI IPA, 6 peserta didik kelas XI IPS, 12 peserta didik kelas XII IPA, dan 9 peserta didik kelas XII IPS baik laki-laki maupun perempuan. Hasil tersebut di dapat setelah peneliti membagikan link kepada seluruh perserta didik Madrasah Aliyah Negeri 2 Bantul.

Untuk mendukung proses pembelajaran di tengah situasi social distancing akibat penyebaran Covid-19, pendidik menggunakan media sosial sebagai media pendukung untuk melakukan pembelajaran. Media sosial adalah media online yang mendukung interaksi sosial. Media sosial menggunakan teknologi berbasis web yang mengubah komunikasi menjadi dialog interaktif. (Nurkarima, 2018) Dengan adanya media sosial, pembelajaran secara daring (dalam jaringan) dapat berjalan dengan mudah. Adapun hubungan komunikasi dengan media sosial adalah sangat erat karena dengan adanya media sosial maka komunikasi menjadi semakin cepat dan mudah untuk dilakukan. (Sari et al., 2018) Di Madrasah Aliyah Negeri 2 Bantul, pendidik juga menggunakan beberapa media sosial untuk mendukung proses pembelajaran di tengah situasi social distancing akibat penyebaran Covid-19. Melalui google form peneliti meminta tanggapan dari peserta didik Madrasah Aliyah Negeri 2 Bantul, mengenai media sosial yang digunakan untuk proses pembelajaran dari pendidik. Media sosial yang digunakan oleh pendidik Madrasah Aliyah Negeri 2 Bantul berdasarkan tanggapan dari peserta didik dapat dilihat pada grafik hasil observasi sebagai berikut : 
Grafik 1. Media sosial yang digunakan untuk mendukung proses pembelajaran secara daring di tengah situasi social distancing akibat penyebaran Covid-19.

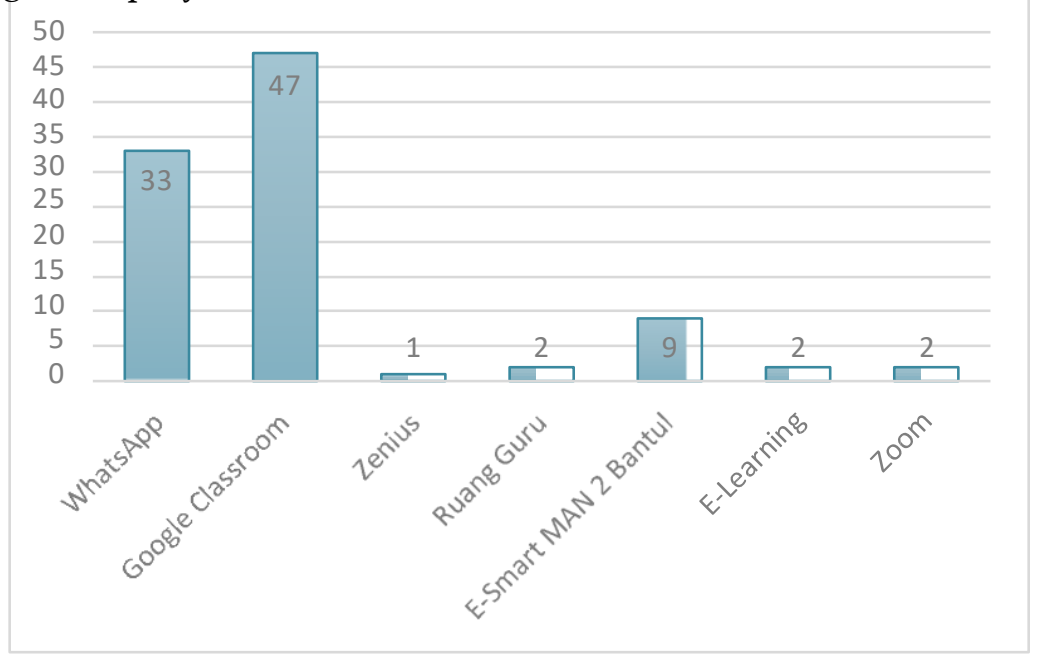

Berdasarkan Grafik 1, dapat terlihat bahwa pendidik di Madrasah Aliyah Negeri 2 Bantul banyak yang menggunakan media sosial Google Classroom sebagai pendukung proses pembelajaran di tengah situasi social distancing saat ini akibat penyebaran Covid-19. Google classroom adalah platform pembelajaran campuran yang dikembangkan oleh google untuk sekolah yang bertujuan menyederhanakan pembuatan, pendistribusian dan penetapan tugas dengan cara tanpa kertas. (Wicaksono \& Rachmadyanti, 2016) Peserta didik dapat dengan mudah menggunakan google classroom jika smartphone atau laptop yang digunakan terhubung dengan internet. Internet merupakan suatu jaringan di mana penggunaannya memerlukan media lainnya seperti komputer, laptop, modem, atau smartphone. Di zaman yang serba maju seperti sekarang ini, internet dikembangkan untuk aplikasi wireless (tanpa kabel) dengan menggunakan smartphone. Hal ini semakin memudahkan bagi kita karena smartphone akan selalu terhubung dengan jaringan internet di manapun dan kapanpun. Smartphone sendiri adalah sebuah telepon genggam yang kegunaannya hampir sama seperti komputer. Akan tetapi smartphone lebih ringkas sehingga bisa dibawa ke mana saja.

Di era yang modern seperti saat ini, penggunaan smartphone bagi peserta didik dirasa sudah menjadi hal yang sangat biasa. Banyak peserta didik yang sudah mempunyai smarphone sendiri. Hal ini tentunya semakin memudahkan pembelajaran yang terjadi secara daring seperti saat ini di tengah situasi social distancing. Apalagi dengan terhubungnya smartphone atau laptop dengan internet, memudahkan pendidik dan peserta didik untuk mengakses google classroom. Dengan google classroom pendidik dapat dengan mudah memberikan materi, dan tugas kepada peserta didik. Peserta didik juga bisa mengumpulkan tugas yang diberikan oleh pendidik melalui google classroom. Media ini dapat menampung dan mengatur waktu pengumpulan tugas oleh pendidik yang tentunya akan menumbuhkan kedisiplinan bagi peserta didik dalam mengerjakan tugas. (Online \& Tadulako, 2020) Jadi, walaupun tidak bertatap muka pendidik tetap menerapkan kedisiplinan bagi peserta didik dalam pengumpulan tugas. Selain penggunaan google classroom sebagai media pendukung, tidak sedikit pula pendidik yang menggunakan media sosial WhatsApp. WhatsApp adalah media komunikasi yang sudah tidak asing lagi bagi masyarakat saat ini. Dengan menggunakan whatApp bisa melakukan percakapan dengan beberapa orang dalam jarak jauh maupun jarak dekat. Melalui menu chat, bisa digunakan untuk copy, delete, dan forward pesan. Selain itu, dengan whatsApp bisa mengirim pesan suara dan membagikan lokasi keberadaan pengguna, dan juga bisa digunakan untuk grup chat, dimana pengguna bisa mengumpulan beberapa kontak untuk dimasukkan ke dalam grup. Dengan adanya grup chat di media sosial WhatsApp memudahkan pendidik untuk berkomunikasi dengan peserta didik tanpa harus menghubungi satu persatu 
kontak dari peserta didik. Karena hampir semua peserta didik mempunyai media sosial tersebut. Sebagai pengelolaan pendidikan, fungsi WhatsApp meliputi kegiatan pengelolaan organisasi kependidikan dan pengelolaan manusia yang terlibat dalam dunia pendidikan. Sedangkan fungsi WhatsApp dalam pengembangan pendidikan meliputi kegiatan pemanfaatan teknologi pendidikan sehingga penggunaan fitur-fitur WhatsApp dalam kegiatan pembelajaran dapat meningkatkan efektifitas pembelajaran. Dengan dibantunya media sosial seperti di atas, semakin memudahkan pendidik dalam melakukan pembelajaran secara daring di tengah situasi social distancing akibat penyebaran Covid-19.

Pendidik berharap beberapa media sosial di atas, dapat mendukung keefektifan pembelajaran dari peserta didik di tengah situasi social distancing akibat penyebaran Covid-19. Akan tetapi, berdasarkan hasil dari observasi peneliti. Tidak semua peserta didik merasa bahwa pembelajaran secara daring (dalam jaringan) ini efektif. Beberapa pendapat dari peserta didik dapat dilihat sebagai berikut :

Grafik 2. Pendapat peserta didik mengenai keefektifan pembelajaran secara daring (dalam jaringan) di tengah situasi social distancing akibat penyebaran Covid-19.

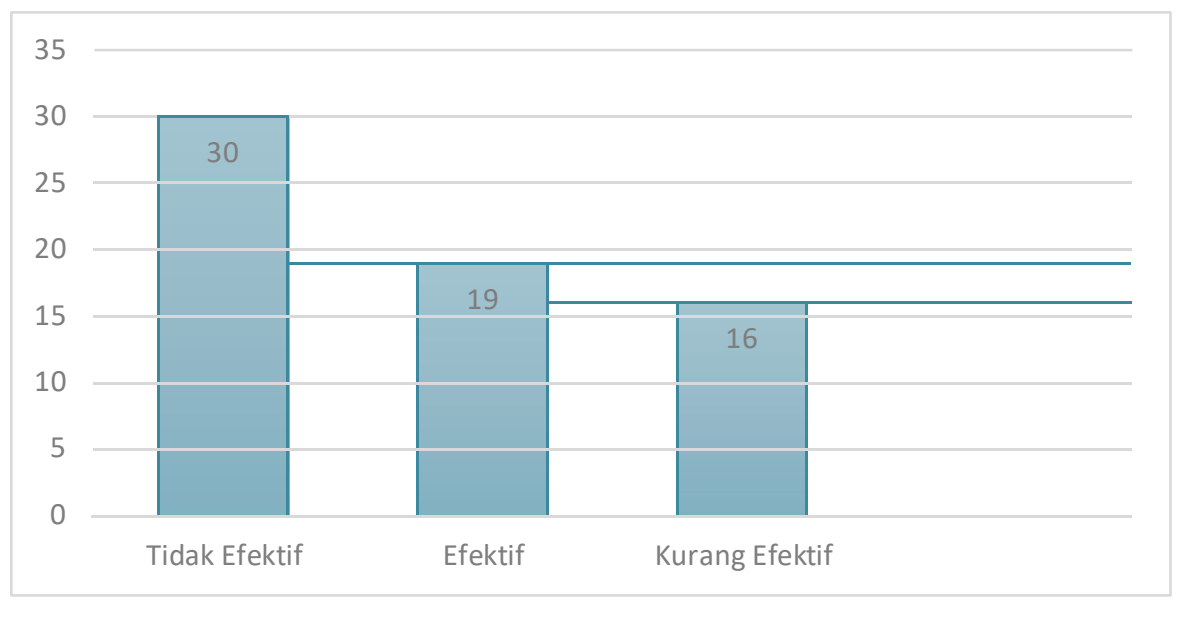

Berdasarkan grafik 2, sebanyak 30 peserta didik berpendapat bahwa pembelajaran secara daring (dalam jaringan) tidak efektif. Kemudian ada 19 peserta didik yang berpendapat bahwa pembelajaran yang dilakukan secara daring (dalam jaringan) dirasa efektif. Dan ada 16 peserta didik yang berpendapat bahwa pembelajaran secara daring (dalam jaringan) kurang efektif. Menurut pendapat peserta didik yang menyatakan pembelajaran tetap berlangsung efektif dikarenakan pendidik tetap memantau proses pembelajaran dari peserta didik walaupun pembelajaran dilakukan secara daring (dalam jaringan). Kedisiplinan dalam mengerjakan dan pengumpulan tugas juga tetap diterapkan oleh pendidik. Akan tetapi ada beberapa peserta didik yang berpendapat bahwa dengan pembelajaran secara daring (dalam jaringan) peserta didik kurang memahami materi dari pendidik. Karena tidak adanya penjelasan secara rinci seperti yang dilakukan pendidik jika pembelajaran dilakukan secara langsung. Meskipun sudah dijelaskan secara rinci, beberapa peserta didik juga kurang memahami, karena ada beberapa peserta didik yang bisa memahami materi pembelajaran jika bertatap muka langsung dengan pendidik.

Dari hasil yang didapatkan peneliti melalui data-data yang sudah diperoleh, peserta didik merasakan bahwa pembelajaran secara daring (dalam jaringan) dirasa tidak efektif. Akan tetapi untuk mendukung pelaksanaan social distancing guna mencegah penyebaran Covid-19, peserta didik tetap harus melakukan pembelajaran secara daring (dalam jaringan) sesuai dengan prosedur yang ada. Agar pembelajaran tetap berjalan efektif, pendidik memberikan motivasi atau arahan kepada peserta didik untuk mempersiapkan otak dalam kondisi siap belajar. Dalam bukunya (Eric Jensen, 2008) menjelaskan pola- pola gelombang otak ini memberikan informasi kapan seseorang siap untuk belajar. Adapun pola-pola gelombang otak sebagai berikut (Rahmadonna, n.d.) : 


$\begin{array}{llll}\text { 1. Delta } & 0-4 \mathrm{~Hz} & t & \text { Tidur nyenyak atau tidak ada kesadaran luar } \\ \text { 2. Theta } & 4-8 \mathrm{~Hz} & t & \text { Setengah tertidur atau tidur-tiduran } \\ \text { 3. Aplha } & 8-12 \mathrm{~Hz} & t & \text { Sadar atau santai atau tenang } \\ \text { 4. Beta } & 12-16 \mathrm{~Hz} & t & \text { Pembangkitan kesadaran normal } \\ \text { 5. High beta } & 16-30 \mathrm{~Hz} & t & \text { Fokus yang intens diarahkan dari luar } \\ \text { 6. K-Compleks } & 30-35 \mathrm{~Hz} & t & \text { Pengalaman "Ah-ha" } \\ \text { 7. Super beta } & 35-150 \mathrm{~Hz} & t & \text { Kondisi ekstrim, tidak sadarkan diri atau di luar } \\ & & & \text { kesadaran tubuh }\end{array}$

Berdasarkan pola-pola gelombang otak di atas, untuk menciptakan keefektifan pembelajaran secara daring (dalam jaringan), peserta didik harus dalam keadaan atau dalam posisi Alpha (sadar, tenang, dan santai). Sehingga, walaupun tidak berinteraksi secara langsung, peserta didik tetap memahami materi yang diberikan pendidik dan peserta didik tetap sigap dalam menangkap pembelajaran dari pendidik apabila peserta didik dalam posisi Alpha (sadar, tenang, dan santai) Ketika peserta didik dalam kondisi pola gelombang otak alpha, pendidik harus bisa memusatkan perhatian dari peserta didik dengan membuat metode pembelajaran secara daring (dalam jaringan) yang terkesan unik. Selama proses pembelajaran, pendidik harus berperan aktif dalam menciptakan suatu proses pembelajaran yang menyenangkan agar dapat menarik perhatian dari peserta didik. Apabila proses pembelajaran yang dilakukan oleh pendidik menyenangkan, maka akan timbul perasaan senang ketika belajar dalam diri peserta didik. Seperti membuat kuis yang nantinya akan memberi nilai tambahan kepada peserta didik yang mengerjakan, atau membuat video tentang pembelajaran sekreatif mungkin. Dengan itu keefektifan pembelajaran secara daring (dalam jaringan) di tengah situasi social distancing akibat penyebaran Covid-19 tetap berlangsung.

Melalui google form pendidik juga meminta pendapat peserta didik mengenai kelebihan dan kekurangan dari sistem pembelajaran secara daring (dalam jaringan) di tengah situasi social distancing akibat penyebaran Covid-19. Beberapa pendapat peserta didik tesebut :

a. Kelebihan

1. Peserta didik lebih mudah belajar dan lebih berkosentrasi

Ada beberapa peserta didik yang lebih memahami materi jika berada di suasana yang tidak ramai. Suasana kelas yang kadang tidak kondusif, membuat beberapa peserta didik kehilangan konsentrasi. Konsentrasi adalah pemusatan pikiran pada suatu hal dengan cara menyampingkan hal-hal lain yang tidak berhubungan. Konsentrasi memungkinkan individu untuk terhindar dari pikiran-pikiran yang mengganggu ketika berusaha untuk memecahkan persoalan yang sedang dihadapi. (Fauziah, 2015) Dengan adanya pembelajaran secara daring (dalam jaringan) di tengah situasi social distancing akibat penyebarab Covid-19 pada saat ini, menguntungkan beberapa peserta didik yang lebih menyukai pembelajaran dengan situasi yang tidak ramai dan kondusif.

2. Jam belajar lebih efektif

Biasanya pada saat peserta didik melakukan pembelajaran secara langsung, jam pembelajaran bisa berlangsung selama 8 jam di Madrasah Aliyah Negeri 2 Bantul. Akan tetapi pada saat pembelajaran secara daring (dalam jaringan), jam pembelajaran berlangsung lebih efektif atau lebih singkat.

3. Waktu belajar atau mengerjakan soal lebih panjang dan lebih leluasa

Ketika berada di dalam kelas, peserta didik diberi soal yang hanya bisa dikerjakan pada saat jam pelajaran itu saja. Pada saat pembelajaran secara daring (dalam jaringan) beberapa pendidik memberi waktu cukup panjang bagi peserta didik untuk memahami soal kemudian menjawab soal tersebut. 
4. Melatih peserta didik menggunakan smartphone dengan hal-hal yang bermanfaat

Perkembangan zaman pada saat ini membuat smartphone sudah familiar diberbagai kalangan masyarakat. Jika tidak berhati-hati dalam penggunaannya, smartphone bisa menimbulkan hal negatif bagi penggunannya. Namun dengan adanya pembelajaran secara daring (dalam jaringan) membuat peserta didik Madrasah Aliyah Negeri 2 Bantul lebih memanfaatkan smartphone dengan hal-hal positif. Karena pendidik lebih sering meminta peserta didik untuk mncari materi pembelajaran menggunakan smartphone. Sehingga peserta didik tidak bisa menggunakan smartphone untuk hal-hal yang bersifat negatif.

5. Melatih kemandirian peserta didik untuk mencari dan mepelajari materi

Pembelajaran secara daring (dalam jaringan) menuntut peserta didik untuk lebih mandiri. Seperti memahami atau mencoba mencari materi pembelajaran secara mandiri. Hal tersebut bisa melatih kemandirian dari peserta didik.

6. Melatih kreatifitas peserta didik

Kreativitas dapat bermakna sebagai kreasi terbaru dan orisinil yang tercipta, sebab kreativitas suatu proses mental yang unik untuk menghasilkan sesuatu yang baru, berbeda dan orisinil. Kreativitas akan menjadi seni ketika seseorang melakukan kegiatan. (R.M, 1994) Dengan pembelajaran secara daring, ada beberapa peserta didik yang melatih kreatifitasnya. Jika ingin membangun fondasi yang relatif kuat untuk kreativitas seorang peserta didik, yang harus dilakukan adalah memperluas pengalaman dan rangsangan-rangsangan yang melibatkan imajinasi kreatif. Semakin banyak peserta didik melihat, mendengar, dan mengalami, semakin ia akan tahu dan berasimilasi, semakin banyak elemen realitas yang akan dimiliki dalam pengalamannya, maka semakin produktif imajinasinya. (Yusmalina \& Suyadi, n.d.) Seperti mempunyai inisiatif sendiri untuk menyalin atau meringkas materi yang diberikan oleh pendidik. Itu sudah menjadi apresiasi tersendiri bagi peserta didik untuk melatih kreatifitas berfikirnya.

7. Menambah wawasan peserta didik dengan hal-hal yang baru

Peserta didik juga bisa menambah wawasan dengan adanya pembelajaran secara daring (dalam jaringan). Karena pembelajaran bisa dilakukan melalui media manapun. Sehingga peserta didik akan lebih banyak mengetahui tentang materi-materi pembelajaran.

8. Mempunyai waktu yang lebih banyak untuk berkumpul atau quality time bersama keluarga

Quality time adalah frekuensi pertemuan antara orang tua dan anak untuk melakukan kegiatan yang berkualitas bersama-sama. Di tengah situasi social distancing akibat penyebarab Covid19 saat ini, peserta didik mempunyai banyak waktu berkumpul bersama keluarga dibanding dengan teman sebayanya. Sehingga peserta didik lebih merasakan kebersamaan bersama dengan keluarganya.

\section{b. Kekurangan}

1. Tidak memahami secara jelas dari materi yang diberikan pendidik

Biasanya pembelajaran dilakukan secara langsung, sehingga peserta didik lebih mudah memahami materi yang diberikan oleh pendidik. Situasi social distancing yang terjadi saat ini tidak memungkinkan peserta didik melakukan interaksi secara langsung. Sehingga pembelajaran dilakukan melalui media sosial. Akan tetapi ada beberapa peserta didik yang kesulitan memahami materi yang diberikan pendidik melalui media sosial.

2. Tidak bisa bertanya secara langsung mengenai materi yang kurang jelas

Di dalam kelas, atau saat pembelajaran dilakukan secara langsung. Peserta didik lebih mudah bertanya kepada pendidik. Dengan pembelajaran secara daring (dalam jaringan) membuat peserta didik kesulitan menanyakan materi yang belum dipahami. 


\section{Cepat bosan}

Peserta didik akan lebih cepat bosan, karena pembelajaran dilakukan sendiri atau melalui media sosial saja.

4. Mata menjadi lelah karena terlalu lama menatap smartphone

Pembelajaran secara daring mengharuskan peserta didik untuk menggunakan smartphone. Padahal penggunaan smartphone yang terlalu lama menyebabkan mata menjadi lelah.

\section{Kesimpulan}

Berdasarkan hasil penelitian tindakan kelas tentang keefektifan pembelajaran di tengah situasi social distancing akibat adanya penyebaran Covid-19 dengan menggunakan media google form atau google formulir yang dibagikan kepada peserta didik Madrasah Aliyah Negeri 2 Bantul. Didapat sejumlah 65 peserta didik yang merespon pertanyaan dari peneliti, baik peserta didik kelas X, XI, maupun XII. Pembelajaran yang biasanya dilakukan secara langsung saat ini dilakukan secara daring (dalam jaringan) dengan menggunakan media sosial sebagai pendukung pembelajaran tersebut. Dari observasi yang dilakukan peneliti, sebagian besar pendidik di Madrasah Aliyah Negeri 2 Bantul menggunakan media sosial Google classroom dan WhatsApp. Dalam pembelajaran secara daring (dalam jaringan) di tengah situasi social distancing yang terjadi saat ini akibat penyebaran Covid-19, sebanyak 30 peserta didik dari 65 peserta didik yang merespon pertanyaan dari peneliti berpendapat bahwa pembelajaran secara daring (dalam jaringan) dirasa tidak efektif. Karena biasanya pembelajaran bisa dikatakan efektif apabila ada interaksi langsung antara pendidik dan peserta didik. Sehingga, ada beberapa peserta didik yang kurang memahami materi yang diberikan oleh pendidik jika tidak diimbangi dengan penjelasan secara langsung. Akan tetapi, ada juga beberapa peserta didik yang berpendapat bahwa pembelajaran secara daring (dalam jaringan) sama efektifnya dengan pembelajaran secara langsung. Agar pembelajaran tetap berjalan efektif, peserta didik seharusnya dalam keadaan atau dalam posisi Alpha (sadar, tenang, dan santai). Sehingga, walaupun tidak melakukan interaksi pembelajaran secara langsung, peserta didik tetap memahami materi yang diberikan oleh pendidik. Sebagai pendidik juga harus menerapkan metode pembelajaran yang terkesan unik agar peserta didik tidak merasa cepat bosan dan pembelajaran tetap berjalan efektif walaupun dilakukan secara daring (dalam jaringan) di tengah situasi social distancing akibat penyebaran Covid-19. Menurut pendapat dari peserta didik, pembelajaran secara daring (dalam jaringan) mempunyai kelebihan dan kekurangan. Akan tetapi untuk mendukung pelaksanaan social distancing guna mencegah penyebaran Covid19, peserta didik tetap harus menjalankan pembelajaran secara daring (dalam jaringan) sesuai dengan prosedur yang ada. 


\section{Referensi}

Alawiyah

F. (2014). madrasah. Jurnal https://jurnal.dpr.go.id/index.php/aspirasi/article/view/449

Aspirasi, $\quad$ 5(1), $\quad 51-58$.

Barlos, K., \& Koutsogianni, S. (2015). efektif. 97(12), 194-200.

Batubara, H. H. (2016). Penggunaan Google Form Sebagai Alat Penilaian Kinerja Dosen Di Prodi Pgmi Uniska Muhammad Arsyad Al Banjari. AL-BIDAYAH: Jurnal Pendidikan Dasar Islam, 8(1), 39-50. https://jurnal.albidayah.id/index.php/home/article/view/91/88

Cruz, A. P. S. (2013). 済無No Title No Title. Journal of Chemical Information and Modeling, 53(9), 16891699. https://doi.org/10.1017/CBO9781107415324.004

Daeng, I. T. M., Mewengkang, N. ., \& Kalesaran, edmon R. (2017). Penggunaan Smartphone Dalam Menunjang Aktivitas Perkuliahan Oleh Mahasiswa Fispol Unsrat Manado. E-Journal Acta Diurna, 6(1), $1-15$.

Fauziah, Z. (2015). Penerapan Metode Jaritmatika pada Mata Pelajaran Matematika Materi Perkalian untuk Meningkatkan Konsentrasi Belajar Siswa Kelas 2B MI Al - Fithrah Surabaya. 14-34.

Gunawan, A. (2015). Efektifitas pembelajaran pendidikan agama islam dengan model. 1-104.

Health, S. C. V. H. H. S.-P. (2006). Information About Social Distancing. Santa Clara County Public Health Department, Social Distancing, http://www.cidrap.umn.edu/sites/default/files/public/php/185/185_factsheet_social_distancing.p df

Hengki, W. (2018). Pendidikan Neurosains Dan Implikasinya Dalam Pendidikan Masa Kini. March, 1-19.

Iii, B. A. B., \& Penelitian, M. (2014). Rosita Komara Dewi, 2014 PENGARUH PENDAPATAN DAN HARGA PAKET TERHADAP PERMINTAAN INTERNET (survey pada mahasiswa pendidikan ekonomi dan bisnis) Universitas Pendidikan Indonesia | repository.upi.edu | perpustakaan.upi.edu. 1-15.

Lubis, C. M., \& Surya, E. (2016). ANALISIS KEEFEKTIFAN BELAJAR MATEMATIKA MELALUI PENDEKATAN STOP THINK DO PADA SISWA MTs. BUDI AGUNG T.P 2013/2014. UNION: Jurnal Ilmiah Pendidikan Matematika, 4(3), 273-282. https://doi.org/10.30738/.v4i3.455

Lubis, M. (2016). Peluang Pemanfaatan Pembelajaran Berorientasi Teknologi Informasi di Lingkup Madrasah (Mempersiapkan Madrasah Berwawasan Global). Tadris: Jurnal Keguruan Dan Ilmu Tarbiyah, 1(2), 147. https://doi.org/10.24042/tadris.v1i2.1063

Mappasiara. (2018). PENDIDIKAN ISLAM (Pengertian, Ruang Lingkup dan Epistemologinya). Inspiratif Pendidikan, 7(1), 147. https://doi.org/10.24252/ip.v7i1.4940

Nurkarima, N. (2018). Pengaruh Penggunaan Media Sosial Terhadap Akhlakul Karimah dan Akhlakul Madzmumah Siswa Di SMAN 1 Kauman Tahun Ajaran 2017/2018. Institutional Repository, 11. http://repo.iain-tulungagung.ac.id/7912/5/Bab II.pdf

Online, J. K., \& Tadulako, U. (2020). Implementasi Pemanfaatan Google Classroom Dalam Proses Pembelajaran Online di Era Industri 4 . 0. 8(1).

Pangestika, N. L. (2018). Pengaruh Pemanfaatan Media Sosial Whatsapp Terhadap Penyebaran Informasi Pembelajaran di SMA Negeri 5 Depok.

R.M, M. (1994). Kreativitas. Mudra (JURNAL SENI BUDAYA), 2, 1-1.

Rahmadonna, S. (n.d.). Teori belajar neuroscience untuk meningkatkan efektifitas belajar mahasiswa teknologi pendidikan pada matakuliah pengembangan bahan ajar cetak.pdf (pp. 1-10).

Rahmat. (2014). Madrasah Sebagai Lembaga Pendidikan Islam (Sistem dan Perkembangannya Sebelum dan Sesudah Kemerdekaan). Rihlah Jurnal Sejarah Dan Kebudayaan, 1(01), 53-68. https://doi.org/10.24252/RIHLAH.V1I01.649

Rahmiyati, S. (2019). Pemanfaatan Aplikasi Google Form dalam Meningkatkan Pelaksanaan Supervisi Pendidikan Pengawas Madrasah. 4(November), 201-209. 
reza irachmat, M. (2015). Peningkatan perhatian siswa pada proses pembelajaran kelas iii melalui permainan. universitas yogyakarta

Saifurrahman. (2019). Desain Pembelajaran Keagamaan Islam Berbasis Neurosains. Al-Murabbi, 6(1), 5573.

Sari, A. C., Indonesia, U. M., Hartina, R., Indonesia, U. M., Awalia, R., Indonesia, U. M., Iriyanti, H., \& Indonesia, U. M. (2018). Komunikasi dan Media Sosial. December.

Suryono. (2014). Pendidikan Islam Dan Modernitas. Jurnal Pemikiran Keislaman, 25(1), 8-9. https://doi.org/10.33367/tribakti.v25i1.162

Trisnani. (2017). PEMANFAATAN WHATSAPP SEBAGAI MEDIA KOMUNIKASI DAN WhatsApp Utilization As Media Communication and Satisfaction In Submission of Messages among People of the Community. Jurnal Komunikasi Media Dan Informatika, 6(3), 1-12.

Wathon, A. (2016). Neurosains dalam pendidikan. JURNAL LENTERA: Kajian Keagamaan, Keilmuan Dan Teknologi, 14(1), 284-294. https://www.neliti.com/publications/177272/neurosains-dalampendidikan

Wicaksono, V. D., \& Rachmadyanti, P. (2016). Pembelajaran Blended Learning melalui Google Classroom di Sekolah Dasar. Seminar Nasional Pendidikan PGSD UMS \& HDPGSDI Wilayah Timur, 513-521. http://hdl.handle.net/11617/9144

Wilder-Smith, A., \& Freedman, D. O. (2020). Isolation, quarantine, social distancing and community containment: pivotal role for old-style public health measures in the novel coronavirus (2019-nCoV) outbreak. Journal of Travel Medicine, 27(2), 1-4. https://doi.org/10.1093/jtm/taaa020

Yusmalina, D., \& Suyadi. (n.d.). Pengembangan Imajinasi Kreatif Berbasis Neurosains dalam Pembelajaran Keagamaan Islam. 14(2), 267-296.

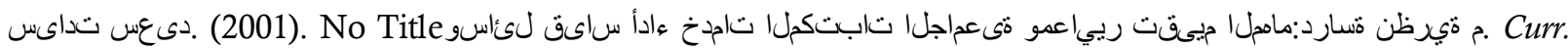
Biol., 11(15), $1155-1167$.

https://www.ncbi.nlm.nih.gov/pubmed/11516946\%0Ahttps://linkinghub.elsevier.com/retrieve/pii /S0960-9822(01)00369-

4\%0Ahttps://www.sciencedirect.com/science/article/pii/S0960982201003694\%0Ahttps://ac.elscdn.com/S0960982201003694/1-s2.0-S0960982201003694-mai 